come back some day and explore it. The address concluded with appreciative remarks regarding the social and recreative work of the institute, and especially with respect to the high place taken in gymnastics. The necessity for laying up for themselves a store of health and strength was strongly impressed upon the students, and the inestimable advantages of the social intercourse made possible by the existence of the various clubs and societies was insisted upon.

\section{CERTAIN PHYSICAL CHARACTERS OF THE NEGROES OF THE CONGO FREE STATE AND NIGERIA.}

I $\mathrm{N}$ a lecture at the Royal Anthropological Institute on November 29, Dr. Arthur Keith dealt with the physical characters and relationships of certain negro tribes in Equatorial Africa. His account was founded on data collected by (I) Mr. E. Torday amongst tribes in the Congo Free State, including the Bushonga, Basoka, Sango, and several others; (2) by Mr. P. A. Talbot in southern Nigeria, including the tribes of the Ekoi, Kabila, and Korawfs. Dr. Keith had also at his disposal three collections of crania, an extensive one of the Batatela (a tribe towards the eastern part of the Congo Free State), which was brought home by Mr. Torday; another from southern Nigeria, which he owed to Mr. P. A. Talbot; and a third (from the delta of the Niger) which had been placed at his disposal by Dr. Frank Corner.

In British Nigeria there are several types, but the one which he regarded as characteristic was represented by individuals of low stature, relatively long-headed, with the skull decidediy flattened from side to side. Many of the physical characters of this Nigerian type can be recognised in the Sango and other Congo tribes bordering on the Sudan. In head form, although not in stature, the Dinkas and Furs of the Nilotic tribes resemble the Nigerian type. In a contracted type which is prevalent in the Congo Free State, and which may be called the Congoese type, the head bulges laterally in the parietal region, and is relatively short and low.

The Batatela and the Basoka are representative of this type. It occurs also in some Nigerian tribes, and also in the Nyam-Nyam and Baran tribes of the Sudan. The Korawfs, a Nigerian tribe near the borders of the German Cameroons, are of a low stature with relatively long arms, as in Sir Harry Johnston's "forest negro type," but in head-form they resemble the Nigerian type of negro. The Bushongo from the south central part of the Congo Free State are tall compared with the Korawfs, but possess the massive head, great span, and large nose of the "forest type." In many features the Bushongo are related to certain of the Sudan tribes, such as the NyamNyam. To account for the present distribution of physical characters among the negro tribes of Equatorial Africa one must assume that there has been a free intermigration of tribes, and that in their evolution the tendency in one tribe has been towards the accentuation of one set of features, in another tribe of another set of characters. Thus in the Nilotic Dinkas high stature and narrowheadedness have become marked characters; in typical Nigerians low stature and narrow heads; in the Bsoka a wide, short head and low stature; in the Buruna a wide head and high stature. Interbreeding may have played a part in the determination of tribal characters; if it had played a great part we should have found a greater degree of physical uniformity. The extent to which an admixture of Arab blood has modified the physical characters of negro tribes has probably been exaggerated.

\section{SCIENCE AND THE STATE. ${ }^{1}$}

$\mathrm{I}^{\mathrm{N}}$ all ages the welfare of a State must have been in a greater or less degree dependent on the development of its material resources and on the vigour and intelligence of its people; it is only in comparatively recent years, however, that recognition has been given to the fact that the State must leave nothing of this to chance, but must set itself deliberately by the use of scientific

I From the presidential address delivered before the South African Association for the Advancement of Science on October $3^{x}$ by Dr. T. Muir, NO. 2 I 46 , VOL. 85$]$ method to make the very best of its resources, and to increase the available vigour and intelligence of everyone within its borders. Not only so, but it must take suitable precautions that intelligence be universally trained, and be also duly organised so as to give the most effective and productive result. It is no longer enough that the State shall merely welcome and applaud a discoverer when he arises, or merely safeguard a private inventor from being fleeced; on the contrary, it must give of its substance to foster both discovery and invention, and must give legislative help to secure that inventions when made shall not be unfruitful through want of skilled labour or other hampering cause.

If we ask the reason for this change, the answer is that the keenness of international competition has vastly increased, that this has led to serious searching of intellect, that the laws of evolution have in consequence been seen to be applicable to nations as well as to individuals, and that under these inexorable laws the very existence of a State may be imperilled by ignorance or neglect. It is thus more important than ever that statesmen and leaders of the people shall not only be men of probity and high general character, but men of wide knowledge and penetrating forethought. They must have studied and must know all the possibilities of both land and people. On the material side they must have reckoned up the mineral resources, the agricultural resources, the water power and other forms of potential energy, the harbour accommodation, the waterways, and the advantages of the geographical position for over-sea commerce. On the human side they must have noted the natural gifts and weak. nesses of the people, the best means of developing the former and of correcting the latter; and if it should be that there are varieties of race and colour in the population they must have thought out plans, not only for preventing loss of power through internal friction, but for obtaining the close cooperation of all the races in the general national interest. In the future it is only in a relative sense that there will continue to be "hewers of wood and drawers of water"; the State that aims at being in the forefront will have to see that even its woodhewing and its water-drawing are done intelligently and to the best advantage. Further, the exploitation of any race in the interest of a higher race will be fatal folly when the need exists for exploiting all races in the interests of the State.

These considerations make it readily appear that the first great duty of the State towards science is to provide an effective and comprehensive system of national education. In the lower stages of the system direct and formal instruction in science need not bulk very largely; what is essential is that the pupil shall throughout his course be trained to observe, to think, and to reason. In the middle stages-the stages covered by secondary schools of all classes-the actual study of science, and especially of scientific method, must form a larger and ever-increasing part of the curriculum. Under neither of these heads, however, need we enter into detail to-night; it is sufficient for our present purpose to insist in connection with both on the desirability ( $I$ ) of fostering rather than repressing the natural curiosity of the young; (2) of constantly recurring to the study of things in supplement to that of words; (3) of training the hands in the use of appropriate tools other than the pen; (4) of gradually introducing research methods into class-room work. It is the neglect of this advice that has been a main cause in the retardation of science; it has also helped to make school life a byword for dulness, and in many cases made the after-life unintellectual and even trivial.

When we come to the higher stages-the stage of the university, and more practical institutions coordinate therewith-the interest in our subject naturally increases, for there we look, not only for instruction in science and training in scientific method, but for a steady flow of fresh contributions to the stock of human knowledge. That this last is a legitimate expectation is now the received opinion throughout the whole civilised world. In accepting it, too, we have but returned to the original conception of a university - a conception that in the course of a long period of years had gradually come to be forgotten in English-speaking countries. The evil results of 
this period of somnolescence at length became so striking, not to say alarming, that in May of 1870 a Royal Commission was appointed in England to make inquiry into the whole matter. It may safely be said that no stronger commission ever sat on a cognate subject, and that its long series of reports are models of clear statement and wise counsel which even to-day it would be difficult to improve upon.

"We have no doubt," one weighty report says, "that for a professor the duty of teaching is indispensable, but we agree that original research is a no less important part of his functions. 'The object of a university is to promote and to maintain learning and science, and scientific teaching of the highest kind can only be successfully carried on by persons who are themselves engaged in original research. If once a teacher ceases to be a learner it is difficult for him to maintain any freshness in the subject which he has to teach; and nothing is so likely to awaken the love of scientific inquiry in the mind of the student as the example of a teacher who shows his value for knowledge by maling the advancement of it the principal business of his life." How far the great English universities then fell short of the ideal here indicated may be gathered from the writings of the time. On the monstrously developed examination system much of the blame had, of course, to be thrown. When it was asked what the universities did with their endowments and equipment, a voice from Cambridge said "they perform the functions, for too many of their students, of first-grade schools merely, and that in a manner about which opinions are divided; and superadded to these is an enormous examining engine, on the most approved Chinese model, always at work." Another writer advised that in order to be honest the university ought to put up a large brass plate with the inscription " Examinations held here"; and there were endless other well-deserved sarcasms from those who knew the facts best.

Of the agitation, the inquiry, and the plain speaking much good came, and the English universities of to-day show in consequence a very different character and spirit. The difference may not be all that earnest reformers still desire, but who in South Africa can with any conscience throw a stone at the offenders? Even so late as Igor, when numerous reforms had been effected in England, a great educationist and chemist, in directing attention to the function performed by universities on the continent of Europe, wound up with the passionate cry:-" Their universities have always been schools of research, of inquiry; unless, and until, ours become such, and our youth can be trained to advance, there can be no hope for us. God help us to make the change before it is too late!" If this be the prayer considered suitable for England when the present century began, what petition will suffice to-day for South Africa, which, as regards university research, stands well in the rear of the England of forty years ago? Are we to be encouraged to hope that one result of this year of union will be a serious effort to uproot our low ideals of university work, and to sow in their place the seeds of true learning and research? Fortunately, in one or two of the "colleges" a few individual teachers have set an excellent example, striving so far as their scant leisure permitted to advance the boundaries of their subject. All honour to them, and may more and more of their students imbibe their spirit and unite to press on the question of university reform and the removal of a deeply engrained stigma.

Coordinate in a sense with universities are public museums and libraries, the link of connection being that, besides intended for the promotion of research, they have other purposes to serve. All of them profess to aim at the instruction of the people; but in the case of museums and libraries this instruction is avowed to be mainly of a popular character, and in the case of museums it often differs very little from that more or less elevated amusement called sight-seeing.

As regards "museums," especially local museums, we have to note that, in the first place, very soldom have their founders had the purposes of real research in their minds. Usually, indeed, the original object has been the formation of a collection of animals, plants, and mere curiosities, with the result that if anything profited thereby it was natural history and archæology alone. Further, a fresh museum has almost uniformly been started without any intention of supplementing or cooperating with those already in existence; much loss in effectiveness has thus been sustained. How best to remedy these initial defects has been a long-standing problem with scientific men, and it is now fairly well agreed (I) that the museums of a country should for purposes of coordination and cooperation be under some common control; (2) that while in local museums appropriate specialisation should be encouraged, no science should be wholly neglected; (3) that both of the main purposes, instruction and research, should receive adequate attention in all museums; (4) that in the case of the central museum the purpose of research should be paramount, all the chief officers being chosen because of their ability to advance the knowledge of their own subjects. We in Cape Town havo in the South African Museum, with its annals, a scientific agency of great national value and of immense promise for the future. Sad it is to think that, while its collections have been rapidly growing in magnitude and importance, the accommodation for exhibiting them remains as it was fifteen years ago.

As regards libraries, the state of matters is not greatly dissimilar. There are more of them it is true; but if the list be arranged in order of merit we have not got far down it when we find that we have parted company with scientific research. Indeed, the libraries that cater for anyone else than the so-called "general reader" are exceedingly few in number; cooperation is thus at least as necessary as in the case of museums. This is especially true in regard to scientific journals and the publications of scientific societies. The number of these is nowadays so great that a long purse is necessary for the maintenance of a complete collection; but by neglecting cooperation we make matters worse than they need be. Here in Cape Town, for example, we have four or five libraries that purchase scientific serials, and, though the libraries are within short distance of one another, duplicate and triplicate copies of some journals are to be found on their tables, while other journals equally important are neglected by them all. The time surely cannot be far distant when this will be rectified, when the importance of such reference libraries will be better appreciated by the State, and when the South African Public Library, having its special annual grant for reference books restored to it, will take the lead in a scheme of cooperation calculated to meet the wants of all engaged in scientific or literary research.

When thus dealing with the functions of universities, museums, and libraries, I have been in a manner viewing the State as an educationist. I now wish, in the same way, to invite your attention to the State as a landlord. With an extensive and varied property calling for development, one of the first and most urgent duties is to have it surveyed and inventoried under every needful heading. In the first place it must be accurately mapped; in the second place its surface constituents and rock formations must be ascertained and registered; in the third place the animal life of every district must be put on record; in the fourth place the same must be done with its plant life; and, lastly, its water supply, rainfall, and other climatic factors must be observed and tabulated. There thus arise as necessary scientific departments of the State's workthe topographical, geological, zoological, botanical, and meteorological. The fact that some of these subjects are incidentally dealt with by college lecturers and private students is no satisfactory reason for negligence on the part of the State. All such outside aid, it must be remembered, is subject to the uncertainties of personal liking, fashion, and caprice, and, consequently, is in its nature fitful and untrustworthy in an emergency. Besides, much of the work wanted to be done requires continuous attention over long periods, so that efficiency can only be secured by the existence of a permanent staff.

Attention has next to be directed to the State's duty in a third capacity, namely, as general health guardian. Fortunately this, though involving consideration of $a$ number of sciences (entomology, bacteriology, mycology, \&c.), need not be enlarged upon, it being self-evident that the bodily and mental fitness of the people is all-important in the life struggle of nations, and that it is almost equally momentous that animals and plants useful to man should be protected from the ravages of disease. Further, there No. 2 I 46 , VOL. 85$]$ 
is the satisfactory reason that in dealing with such matters South African Governments have been, on the whole, sympathetic and, in some directions, markedly liberal. Here again, however, and pi-haps in a special degree, it is necessary to give warning that the State should not burden itself with work proper to individuals and private corporations, but should confine itself to needful scientific work which other agencies cannot accomplish. It should never be forgotten that the State which discourages selfhelp is undermining its own strength.

Thus far we have been considering sciences with direct practical applications; indeed, the reasons for considering them at all has been in the main because of the existence of these applications-because the sciences bear more or less immediately on the welfare and prosperity of the State. What, then, are we to say of sciences from which the State or its people cannot hope to obtain any immediate benefit? Our answer is-and it ought to be given with entire frankness-such sciences must be content to take a second place. The State, we feel, has a perfect right to expect something tangible in return for its outlay; and, its supply of funds being limited, it is bound to pass in review before it any proposed series of scientific schemes, separating them out into practical and impractical, and thereafter sifting the practical into those that are urgent and those that are not. A manifest danger, however, besets the discriminators between rival schemes, it being far from easy to foresee what particular research will prove fruitful of practical applications and what will not. How often has one seen the pure mathematics of to-day change into the applied mathematics of to-morrow, and the previously despised insect collector being hailed shortly afterwards as a benefactor of mankind! All that one can hope for is that those with whom such decisions rest will always take the best advice available. Of recent years European Governments have tended more and more in such cases to consult their great leading scientific corporations; the Government of the Union may in like manner find our own Royal Society a willing and useful guide. I would merely add as a fact worth ruminating on that the States which have differentiated least between pure and applied science are the States which lead the world to-day.

While thus whole-heartedly urging the great importance of science on those who may be called to administer the affairs of State, it would be unfair to ignore the difficulties and troubles which well-disposed administrators are said to have experienced in their dealings with scientific men, or " experts," as they prefer to call them. The complaint of the most moderate of these critics is that the man of science is normally unpractical, and that his value to the State is marred by eccentricities due to over-study or excessive specialisation; and those critics who are not moderate, and who love a biting phrase better than strict accuracy, say that when he is not an astute self-seeker he is either a mooning pedant or a pernicious crank. Now in regard to this I should first wish to ask whether it be not the case that the failure of the scientific expert is often due to causes wholly outside himself. Time and again one has seen a man chosen for his high qualifications in a special branch of knowledge, and then set, not to the work of extending this knowledge by investigation, but to the absolutely diverse work of "running" a Government office or carrying on a purely business undertaking. Failure, nine times out of ten, is thus inevitable, so rare is it to find the successful student and the capable administrator combined in one. Surely it is the merest common sense to urge that if both sets of qualifications be wanted, reasonable care should be taken either that they are possessed by the same individual or that a practicable arrangement involving their separation has been previously devised. One thing certain is that in particular the appellation "self-seeking" as applied to men of science is singularly unfortunate, for, though the man of science with such a bent is not unknown, one's whole experience is that he is a comparative rarity, and that the more zeal a man has for science the less regardful he is of self. Indeed, it has been maintained that in the virtues of unselfishness and truthfulness the man who has chosen the pursuit of science for his life-work noteworthily excels. No less an authority than Helmholtz, himself a man of the world as well as a great investigator, has spontane-

NO. 2 I 46 , VOL. 85] ously testified to this, speaking with enthusiasm of the scientific man's "Sittenstrenge" and his "Uneigennützige Begeisterung." Unfortunately, it is possible that this "Sittenstrenge" is exactly what our public men would consider an eccentricity, their short-sightedness leading them to mistake a surface freckle for a deep-seated defect.

$\mathrm{Be}$ all this as it may, however, it is important to urge on both sides the fact that the man of science and the man of affairs, whatever their respective frailties may be, have need of each other, and must therefore in the future strive to know each other better, and learn to cooperate more effectively in the interest of the State. To this end he who aims at State administration must seek to possess other qualities and other aptitudes than those of the mere party politician, so that, besides doing his own proper work well, he may be the better able to gauge the value of pure scientific work, and be the better fitted to sympathise with the ideals and aspirations of even the extremest of specialists. On the other hand, the specialist must aim a little more at width of outlook and knowledge of men and affairs, must seek to moderate his exaggerated estimate of the importance of his own little domain, and must try to see good in the labours of other specialists in fields far distant from his own, never forgetting that all fields are but perfectly fitted portions of a cosmic whole, and that, as the botanist and the astronomer in particular must come to know,

Thou canst not stir a flower

Without troubling a star.

It would be a neglected opportunity if we did not note in passing that the need for a good understanding between the devotee of statecraft and the student of science is only part of a much wider need. Men who aspire to be leaders in municipal affairs, in commerce, in trade, in the manufacturing industries, in agriculture, must all come to know how substantially dependent they are upon science, and how, indeed, in a very real way, they must become more and more scientific themselves in the conduct of their affairs. With them also the day is gone when rule-ofthumb is a sufficient guide. Even sound common sense, so great a standby in the past, is no longer enough : what is wanted is that glorified form of common sense known as scientific method. Practical men in every line of life are beginning to see this, though they may not use the term. In plain language, what it means is the employment, at every stage of a process or undertaking, of the means best suited to attain the desired end. And as a method it is always essentially the same, no matter how the desired end may vary-whether the latter be, as we in Cape Colony have seen it to be, the sanitation of a town, the tracking of a crime, the repression of a native rebellion, the fighting of an invading disease, or the capturing of a market for fruit or wool. In all of these there was the same need for collecting accurate data, using all previously acquired relevant knowledge, planning skilfully a course of procedure, selecting wisely the human agents necessary, and then prosecuting with steady persistency the plan resolved on.

I need hardly say, in conclusion, that all that the most enlightened State can do will never be fully effective without a continuance of that zeal and devotion on the part of the "private worker" which has been so conspicuous in the past history of science; and, fortunately, in the course of evolution man has become so constituted that a stoppage of the supply need not be feared. Many will still be found willing and eager to work for the work's sake, whether the State does its duty or the reverse. merely resting on the assurance that "Nature never did betray the heart that truly 'loved her.' "'

\section{UNIVERSITY AND EDUCATIONAL}

\section{INTELLIGENCE}

Cambridge.--The special board for biology and geology has adiudged the Walsingham medal for Ioro to $A$. V. Hill, of Trinity College, for his essay entitled "The Heat Produced by Living Tissues, with Special Reference to Muscular Activity"; and a second Walsingham medal to J. C. F. Fryer, of Gonville and Caius College, for his essay entitled "The Structure and Formation of Aldabra and Neighbouring Islands-with Notes on their Flora and Fauna." 